\title{
Does an Increase in Membrane Unsaturated Fatty Acids Account for Tween 80 Stimulation of Glucosyltransferase Secretion by Streptococcus salivarius?
}

\author{
By NICHOLAS A. JACQUES, $\dagger$ VIRGINIA L. JACQUES, \\ ANITRA C. WOLF AND CHARLES L. WITTENBERGER* \\ Microbiology Section, Laboratory of Microbiology and Immunology, National Institute of Dental \\ Research, National Institutes of Health, Bethesda, Maryland 20205, USA
}

(Received 29 May 1984; revised 22 August 1984)

\begin{abstract}
When Streptococcus salivarius was grown in batch culture in the presence of various Tween detergents, the fatty acid moiety of the detergent was incorporated into the lipids of its membrane. Tween 80 (containing primarily oleic acid) markedly stimulated the production of extracellular glucosyltransferase and also increased the degree of unsaturation of the membrane lipid fatty acids. The possibility that an increase in membrane unsaturated fatty acids promoted extracellular glucosyltransferase production was examined by growing cells at different temperatures in the presence or absence of Tween 80 . The membrane lipids of cells grown at $30{ }^{\circ} \mathrm{C}, 37^{\circ} \mathrm{C}$ and $40^{\circ} \mathrm{C}$ without Tween 80 exhibited unsaturated/saturated fatty acid ratios of $2.06,1.01$ and 0.87 respectively. A significant increase in the production of extracellular glucosyltransferase was observed at $30^{\circ} \mathrm{C}$ compared to cells grown at $40^{\circ} \mathrm{C}$. However, cells produced much more exoenzyme at all temperatures when grown with Tween 80 . The results indicated that an increase in the unsaturated fatty acid content of the membrane lipids was not by itself sufficient to account for the stimulation of extracellular glucosyltransferase production by Tween 80 , but that the surfactant also had to be present.
\end{abstract}

\section{INTRODUCTION}

The ability of certain oral streptococci to synthesize water insoluble glucans is related to their colonization and establishment on tooth surfaces (Gibbons \& Banghart, 1967; Gibbons \& Fitzgerald, 1969; Gibbons \& van Houte, 1975). However, the mechanism of control over the production of the extracellular glucosyltransferase enzymes responsible for the formation of glucan remains to be elucidated. The amount of glucosyltransferase produced by oral streptococci varies markedly depending upon the composition of the growth medium (Carlsson \& Elander, 1973; Schachtele et al., 1976; Janda \& Kuramitsu, 1976; Umesaki et al., 1977; Wittenberger et al., 1978), the growth rate, and the carbohydrate available to the organism in continuous culture (Carlsson \& Elander, 1973; Hamilton et al., 1979; Hardy et al., 1981). In particular, the enhancement of glucosyltransferase synthesis and secretion by the non-ionic surfactants Emanon 4115 (polyethylene glycol mono-oleate) and Tween 80 (polyoxyethylene sorbitan mono-oleate) (Umesaki et al., 1977; Wittenberger et al., 1978) has implicated the cell membrane as one possible controlling factor in the production of the extracellular enzyme. In

† Present address: Institute of Dental Research, 2 Chalmers Street, Surry Hills, New South Wales 2010, Australia.

$\ddagger$ Present address: School of Chemical Engineering and Industrial Chemistry, University of New South Wales, Kensington, New South Wales 2044, Australia.

Ahhretiation: U/S, ratio of unsaturated to saturated. 
the case of Streptococcus salivarius (Jacques, 1983) and S. mutans (Umesaki et al., 1977), Tween 80 has been shown to increase the octadecenoic acid content of the lipid bilayer and it has been suggested that an increase in fluidity of the membrane lipids might facilitate glucosyltransferase secretion, thereby enhancing its rate of synthesis (Umesaki et al., 1977; Wittenberger et al., 1978). In this paper it will be shown that simple enrichment of $S$. salivarius membrane lipids with unsaturated fatty acids is not the sole factor in the Tween 80 mediated stimulation of extracellular glucosyltransferase production.

\section{METHODS}

Organism and medium. Streptococcus salivarius ATCC 25975 was used throughout these studies and was grown in a chemically-defined medium (Wittenberger et al., 1978). Stock cultures were stored at $4{ }^{\circ} \mathrm{C}$ in defined medium containing excess $\mathrm{CaCO}_{3}\left(20 \mathrm{mg} \mathrm{ml}^{-1}\right)$. Stocks were transferred to fresh medium every month. Glucose $(0 \cdot 4 \%$, $\mathrm{w} / \mathrm{v}$ ) served as the fermentable carbon source in all experiments.

Materials. [U-glucosyl-14 C]sucrose was purchased from New England Nuclear; $\mathbf{B F}_{3}$ in methanol, fatty acid standards and the gas-liquid chromatographic column packing $(10 \%(w / w)$ SP-2330 on 100/200 Chromosorb) were obtained from Supelco, Bellefonte, Pa., USA. Tweens 20, 40, 60 and 80, containing dodecanoic, hexadecanoic, octadecanoic and octadecenoic acid substituents respectively, were purchased from Sigma.

Growth measurements. S. salivarius was grown at $37^{\circ} \mathrm{C}$ in screw cap bottles containing $100 \mathrm{ml}$ defined medium. Growth was monitored with a Klett-Summerson colorimeter equipped with a $660 \mathrm{~nm}$ filter (Klett Manufacturing Co., New York, NY, USA); 100 Klett units were equivalent to a cell dry weight of $0.36 \mathrm{mg} \mathrm{m}^{-1}$. When cells were cultured at different temperatures, the inoculum was first grown through one transfer at the desired temperature except where otherwise indicated in the text.

Assay of glucosyltransferase. Total extracellular glucosyltransferase activity was measured in samples taken from growing cultures. Cells were removed by vacuum filtration through $0 \cdot 45 \mu \mathrm{m}$ Nalgene filter units (Nalge Company) and the filtrates were assayed with $\left[\mathrm{U}-\right.$ glucosyl- $\left.{ }^{14} \mathrm{C}\right]$ sucrose according to a modification (Wittenberger et al., 1978) of the procedure described by Robrish et al. (1972). One unit of enzyme activity (U) was defined as the amount of glucosyltransferase that catalysed the incorporation of $1 \mu \mathrm{mol}$ of the glucose moiety of sucrose into $75 \%$ ethanolinsoluble polysaccharide $\mathrm{min}^{-1}$. In all cases, the specific activity of glucosyltransferase was expressed as $U$ (mg dry wt) $)^{-1}$.

Preparation and analysis of fatty acids. Samples of cells for fatty acid analysis (10 to $50 \mathrm{ml}$ cultures) were harvested by centrifugation $\left(10000 \mathrm{~g}, 4{ }^{\circ} \mathrm{C}, 10 \mathrm{~min}\right)$, washed and resuspended in distilled water $(2.5 \mathrm{ml})$. The membrane lipids were extracted according to the method of Bligh \& Dyer (1959), and methyl esters were prepared (Jacques, 1982) and analysed as reported previously (Jacques, 1983).

\section{RESULTS}

\section{Influence of Tween detergents on the membrane fatty acids}

The fatty acid profile of the membrane lipids of $S$. salivarius was significantly altered when cells were grown in the presence of Tween $20,40,60$ or 80 (Table 1). In all instances except one, the major increase in the membrane fatty acids corresponded to the fatty acid component of the added detergent. The one exception to this pattern occurred with cells grown in the presence of Tween 20, where the dodecanoic acid substituent of the surfactant was not detected in the membrane lipids and may have been elongated to hexadecanoic acid (Table 1). Organisms grown in detergents containing a saturated fatty acid substituent (Tween 20, 40 and 60) also possessed decreased levels of octadecenoic acid. While these results do not preclude de novo synthesis by the organism of specific fatty acids corresponding to those in a given Tween detergent, it is more likely that the fatty acid substituent of the detergent was released by hydrolysis and incorporated directly into the membrane lipids. It was also shown that direct adsorption of the detergents to the cells did not occur. When cells were grown in medium without added surfactants and then incubated at $4{ }^{\circ} \mathrm{C}$ for $30 \mathrm{~min}$ with the various Tweens, no alterations in the fatty acid profile were observed. Moreover, analysis of the fatty acid profiles of cells sampled throughout exponential growth in the presence or absence of Tweens revealed that the pattern of the fatty acid profile was established in late lag/early exponential phase and was thereafter constant throughout growth (data not shown). 
Table 1. Fatty acid profile of $S$. salivarius grown in the presence and absence of various Tween detergents

Cells were grown at $37^{\circ} \mathrm{C}$ in the absence of Tween detergents and were inoculated $(10 \%, v / v)$ into $100 \mathrm{ml}$ volumes of medium and grown to late exponential phase. The values in bold type correspond to the fatty acid present in the Tween detergent added to the culture medium. In the case of Tween 20 , the fatty acid substituent dodecanoic acid was not detected in the membrane lipids. The Tweens were each present at a final concentration of $0.05 \%(\mathrm{v} / \mathrm{v})$. The standard error for any given fatty acid was $0 \cdot 1 \%$ (three analyses).

Fatty acid composition $(\%$ of total)

\begin{tabular}{|c|c|c|c|c|c|}
\hline Fatty acid & No Tween & Tween 20 & $\begin{array}{c}\text { Growth condition: } \\
\text { Tween } 40^{*}\end{array}$ & Tween 60 & Tween 80 \\
\hline Dodecanoic $\left(\mathrm{C}_{12: 0}\right)$ & - & - & - & - & - \\
\hline Tetradecanoic $\left(\mathrm{C}_{14: 0}\right)$ & $5 \cdot 1$ & $8 \cdot 6$ & $3 \cdot 2$ & $5 \cdot 6$ & $3 \cdot 5$ \\
\hline Hexadecanoic $\left(C_{16: 0}\right)$ & $39 \cdot 4$ & $56 \cdot 5$ & 69.5 & $47 \cdot 3$ & $28 \cdot 6$ \\
\hline Hexadecenoic $\left(\mathrm{C}_{16: 1}\right)$ & $10 \cdot 9$ & $7 \cdot 7$ & $6 \cdot 1$ & $10 \cdot 1$ & $11 \cdot 8$ \\
\hline Unknown & - & - & 1.9 & $1 \cdot 2$ & $1 \cdot 0$ \\
\hline Octadecanoic $\left(\mathrm{C}_{18: 0}\right)$ & $5 \cdot 2$ & $7 \cdot 1$ & $4 \cdot 3$ & $20 \cdot 7$ & $3 \cdot 8$ \\
\hline Octadecenoic $\left(\mathrm{C}_{18: 1}\right)$ & $29 \cdot 9$ & 17.9 & $11 \cdot 3$ & $11 \cdot 4$ & $42 \cdot 7$ \\
\hline Eicosenoic $\left(C_{20: 1}\right)$ & $9 \cdot 0$ & $2 \cdot 2$ & $2 \cdot 2$ & 1.9 & $7 \cdot 7$ \\
\hline
\end{tabular}

- , Not detected.

* Growth in the presence of Tween 40 was slow. The values given are for cells grown for $24 \mathrm{~h}$.

Table 2. Extracellular glucosyltransferase production in the presence or absence of various Tween detergents

Cells were grown at $37^{\circ} \mathrm{C}$ in $100 \mathrm{ml}$ cultures to the late exponential phase of growth in all cases, except for the culture to which Tween 40 had been added where growth was much slower and cells were harvested after $24 \mathrm{~h}$. All Tweens were present at a concentration of $0.05 \%(\mathrm{v} / \mathrm{v})$.

\section{Addition to} growth medium

No Tween

Tween 20

Tween 40

Tween 60

Tween 80

\section{Total growth time (min)}

180
200
1440
360
200

$\mathrm{U} / \mathrm{S}^{*}$ ratio

$1 \cdot 01$
0.39
0.26
0.34
1.65

Extracellular glucosyltransferase [mU (mg dry wt $)^{-1}$ ]
$31 \cdot 8$
$96 \cdot 3$
$194 \cdot 4$
$315 \cdot 0$
$636 \cdot 0$

* Ratio of unsaturated to saturated fatty acids in membrane lipids (calculated from the data in Table 1).

\section{Effect of Tweens on extracellular glucosyltransferase production}

Tweens 20, 40 and 60 stimulated extracellular glucosyltransferase production and this stimulation appeared to be related to the chain length of the fatty acid moiety of the surfactant. Tween 80 , however, was clearly the most effective in enhancing glucosyltransferase production and it was also the only detergent that increased the unsaturated/saturated (U/S) fatty acid ratio of the cell membrane (Table 2). The increase in the U/S ratio appeared to be due to the incorporation of the octadecenoic acid moiety of Tween 80 into the membrane lipids at the expense of hexadecanoic and octadecanoic acids (Table 1).

\section{Effect of temperature on the membrane fatty acids and glucosyltransferase production}

The possibility was investigated that the increase in the unsaturated fatty acid content of the membrane lipids of cells grown with Tween 80 was directly responsible for the stimulation of extracellular glucosyltransferase production. In Escherichia coli, it is known that the membrane lipids are enriched with unsaturated fatty acids when the organism is grown at suboptimal temperatures (Marr \& Ingraham, 1962). Accordingly, S. salivarius was grown at $30^{\circ} \mathrm{C}, 37^{\circ} \mathrm{C}$, and $40^{\circ} \mathrm{C}$ in the presence and absence of Tween 80 . The fatty acid composition of the membrane 
Table 3. Effect of temperature on the membrane lipid fatty acids of $S$. salivarius grown in the presence or absence of Tween 80

Cells grown in the absence of Tween 80 at the appropriate temperature were inoculated $(10 \%, v / v)$ into $100 \mathrm{ml}$ of medium and grown to late exponential phase. The standard error for any given fatty acid was $0.1 \%$ (three analyses). Where indicated, Tween 80 was present at $0.05 \%(\mathrm{v} / \mathrm{v})$.

\begin{tabular}{|c|c|c|c|c|c|c|}
\hline \multirow[b]{3}{*}{ Fatty acid } & \multicolumn{6}{|c|}{ Fatty acid composition $(\%$ of total) } \\
\hline & \multicolumn{2}{|c|}{$\underbrace{30} \underbrace{\circ} \mathrm{C}$} & \multicolumn{2}{|c|}{$\begin{array}{c}\text { Growth condition: } \\
37{ }^{\circ} \mathrm{C}\end{array}$} & \multicolumn{2}{|c|}{$40^{\circ} \mathrm{C}$} \\
\hline & No Tween & Tween 80 & No Tween & Tween 80 & No Tween & Tween 80 \\
\hline Tetradecanoic $\left(\mathrm{C}_{14: 0}\right)$ & $0 \cdot 8$ & $0 \cdot 6$ & $5 \cdot 1$ & $3 \cdot 5$ & $3 \cdot 9$ & $1 \cdot 4$ \\
\hline Hexadecanoic $\left(\mathrm{C}_{16: 0}\right)$ & $26 \cdot 1$ & $17 \cdot 7$ & $39 \cdot 4$ & $28 \cdot 6$ & $42 \cdot 1$ & $33 \cdot 5$ \\
\hline Hexadecenoic $\left(\mathrm{C}_{16: 1}\right)$ & $7 \cdot 3$ & $7 \cdot 4$ & $10 \cdot 9$ & $11 \cdot 8$ & $6 \cdot 3$ & $6 \cdot 4$ \\
\hline Unknown & - & $0 \cdot 9$ & - & $1 \cdot 0$ & - & 0.7 \\
\hline Octadecanoic $\left(\mathrm{C}_{18: 0}\right)$ & $5 \cdot 8$ & $2 \cdot 6$ & $5 \cdot 2$ & $3 \cdot 8$ & $7 \cdot 6$ & $6 \cdot 1$ \\
\hline Octadecenoic $\left(\mathrm{C}_{18: 1}\right)$ & $43 \cdot 9$ & $58 \cdot 0$ & $29 \cdot 9$ & $42 \cdot 7$ & $29 \cdot 9$ & $42 \cdot 0$ \\
\hline Eicosenoic $\left(C_{20: 1}\right)$ & $16 \cdot 0$ & $12 \cdot 7$ & $9 \cdot 0$ & $7 \cdot 7$ & $10 \cdot 2$ & $9 \cdot 8$ \\
\hline $\mathrm{U} / \mathrm{S}^{*}$ ratio & $2 \cdot 06$ & $3 \cdot 74$ & 1.01 & $1 \cdot 65$ & $0 \cdot 87$ & 1.42 \\
\hline
\end{tabular}

Table 4. Effect of temperature on the unsaturated/saturated fatty acid ratio of the membrane lipids and the amount of glucosyltransferase produced in the presence and absence of Tween 80

$\begin{array}{cccc}\begin{array}{c}\text { Growth } \\ \text { Temp. }\end{array} & \begin{array}{c}\text { Tween } 80 \\ (0.05 \%, \mathrm{v} / \mathrm{v})\end{array} & \mathrm{U} / \mathrm{S}^{*} \text { ratio } & \begin{array}{c}\text { Extracellular } \\ \text { glucosyltransferase } \dagger \\ {\left[\mathrm{mU}(\mathrm{mg} \mathrm{dry} \mathrm{wt})^{-1}\right]}\end{array} \\ 30^{\circ} \mathrm{C} & - & 2 \cdot 06 & 67.9 \\ 30^{\circ} \mathrm{C} & + & 3.74 & 309.6 \\ 37^{\circ} \mathrm{C} & - & 1.01 & 31.8 \\ 37^{\circ} \mathrm{C} & + & 1.65 & 641.7 \\ 40^{\circ} \mathrm{C} & - & 0.87 & 13.2 \\ 40^{\circ} \mathrm{C} & + & 1.42 & 1235.0\end{array}$

* Ratio of unsaturated to saturated fatty acids in membrane lipids (data from Table 3 ).

† Samples from cultures described in Table 3.

lipids was then analysed and the amount of glucosyltransferase present in the culture supernatants was assayed. Cells grown at $30^{\circ} \mathrm{C}$ without Tween 80 had a membrane lipid fatty acid profile very similar to that found in cells grown at $37^{\circ} \mathrm{C}$ or $40^{\circ} \mathrm{C}$ in the presence of Tween 80 (Table 3). All three growth conditions resulted in an increase in the $\mathrm{U} / \mathrm{S}$ fatty acid ratio of the membrane lipids compared to cells grown at $37^{\circ} \mathrm{C}$ or $40^{\circ} \mathrm{C}$ without Tween 80 and in all three cases this was due largely to an increase in octadecenoic acid and a decrease in hexadecanoic acid. Although cells grown at $30^{\circ} \mathrm{C}$ without Tween $80(\mathrm{U} / \mathrm{S}=2 \cdot 06)$ produced significantly more extracellular glucosyltransferase than cells grown without Tween 80 at $37^{\circ} \mathrm{C}(\mathrm{U} / \mathrm{S}==1.01)$ or $40{ }^{\circ} \mathrm{C}(\mathrm{U} / \mathrm{S}=0.87)$, they produced much less exoenzyme than cells grown in its presence at all three temperatures (Table 4). This suggests that simple enrichment of the membrane lipids with unsaturated fatty acids was not the sole explanation for the dramatic stimulation of extracellular glucosyltransferase production by Tween 80 .

\section{DISCUSSION}

Prior reports have shown that Tween 80 markedly stimulates the production of extracellular glucosyltransferase by $S$. salivarius (Wittenberger et al., 1978) and by $S$. mutans (Umesaki et al., 1977). The mechanism by which this occurs, however, has not been resolved. In the case of $S$. salivarius, it is not exclusively a consequence of the surfactant acting directly on the cell membrane to facilitate export of the enzyme. Other Tweens were far less effective than Tween 80 in stimulating glucosyltransferase production (Table 2) and detergents such as Triton X-100, 
when added to the medium at sub-growth inhibitory concentrations, were ineffective in promoting the production of this enzyme (Wittenberger et al., 1978).

The major difference between Tween 80 and the other surfactants in this series is that Tween 80 contains a mono-unsaturated fatty acid (oleate). The increase in unsaturated fatty acids (predominantly $\mathrm{C}_{18: 1}$ ) in the membrane lipids that accompanied growth of $S$. salivarius in medium containing Tween 80 (Table 1) appears to be a contributing factor in the stimulation of extracellular glucosyltransferase production (Table 2). The membrane lipids of cells grown at $30{ }^{\circ} \mathrm{C}$ without detergent were also enriched with unsaturated fatty acids (again, predominantly $\mathrm{C}_{18: 1}$ ) and these cells too produced more extracellular glucosyltransferase than cells grown at $37^{\circ} \mathrm{C}$ or $40^{\circ} \mathrm{C}$ without Tween 80 (Table 4). The increase in octadecenoic acid that occurred in the temperature shift-down experiments without Tween 80 may have been due to an increase not in oleic acid but in its isomer, cis-vaccenic acid. This has been reported to occur in E. coli (Marr \& Ingraham, 1962; Kito et al., 1975; Evkokimova et al., 1978; de Mendoza \& Cronan, 1983). Moreover, the predominant $\mathrm{C}_{18: 1}$ fatty acid normally found in streptococcal membrane lipids is cis-vaccenic acid (Hoffmann \& Tausig, 1955). The analytical procedures used in this study could not distinguish between the octadecenoic acid isomers. It remains to be established, therefore, whether the isomeric configuration of the octadecenoic acid species in the $S$. salivarius membrane lipids is also important in the synthesis and export of glucosyltransferase.

However, the simple enrichment of the $S$. salivarius membrane lipids with unsaturated fatty acids, and the assumed attendant increase in membrane fluidity (Kimura \& Izui, 1976; Cronan \& Gelmann, 1975; Evkokimova et al., 1978; Nesmeyanova, 1982), is not the sole requirement for maximum production of extracellular glucosyltransferase. Cells grown at $30^{\circ} \mathrm{C}$ without Tween 80 had a U/S ratio (2.06) greater than cells grown at $37^{\circ} \mathrm{C}$ or $40^{\circ} \mathrm{C}$ with the detergent ( 1.65 and 1.42; Table 3), yet produced only about one-tenth as much extracellular glucosyltransferase (Table 4). Cells grown in the presence of Tween 80 produced much more glucosyltransferase at all three temperatures than cells grown without the detergent.

The conditions, therefore, that gave maximal glucosyltransferase production at all temperatures were those in which the cell membrane was enriched with unsaturated fatty acids and Tween 80 was also present in the growth medium. One interpretation of these results is that Tween 80 serves two functions. First, it is a source of oleic acid which, after hydrolysis from the detergent, is incorporated directly into the membrane bilayer. Second, by virtue of its amphiphilic properties, the surfactant might then interact physicochemically with the altered membrane so as to facilitate glucosyltransferase translocation. Ample precedent exists for amphiphilic compounds interacting directly with bacterial membranes to alter membrane functions (Fishman et al., 1980; Petit-Glatron \& Chambert, 1981; Jacques, 1983). A prediction of this hypothesis is that surfactants other than Tween 80 might stimulate maximal glucosyltransferase production in $S$. salivarius cells whose membrane lipids were previously enriched with oleate. We have found that washed cell suspensions, prepared from cells grown at $37^{\circ} \mathrm{C}$ in defined medium containing Tween $80(\mathrm{U} / \mathrm{S}=2.45)$ and incubated in a non-growthsupporting medium, produced nearly equal amounts of extracellular glucosyltransferase in response to Tween 40 , Tween 60 or Tween 80 (unpublished observation). We have not determined, however, whether any alterations in the fatty acid composition of the lipid bilayer occurred during the incubation period with Tweens containing the saturated fatty acids.

It remains to be established whether the postulated dual role of Tween 80 explains the enhanced production of extracellular glucosyltransferase by $S$. salivarius. The cell membrane potential is important in the maturation of exported proteins in E. coli (Enequist et al., 1981; Daniels et al., 1981) and depolarization of the membrane prevents export of these proteins (Pages \& Lazdunski, 1982). Keevil et al. (1984) have also shown that in Streptococcus sanguis, the modulation of protonmotive force across the energized membrane by varying the $\mathrm{Na}^{+} / \mathrm{K}^{+}$ratio significantly affects the secretion of glucosyltransferase. It is interesting to speculate that enrichment of the $S$. salivarius lipid bilayer with unsaturated fatty acids, and the subsequent physicochemical interaction of the bilayer with Tween 80 , might affect the electrochemical gradient, or a specific combination of lipid interactions and the gradient, so as to facilitate the translocation of glucosyltransferase. 
N. A. Jacques was the recipient of a Fogarty International Visiting Fellowship and V. L. Jacques was a Guest Worker at the National Institute of Dental Research, Bethesda, Maryland, USA.

\section{REFERENCES}

BLIGH, E. G. \& DYER, W. J. (1959). A rapid method of total lipid extraction and purification. Canadian Journal of Biochemistry and Physiology 37, 911-917.

Carlsson, J. \& Elander, B. (1973). Regulation of dextransucrase formation by Streptococcus sanguis. Caries Research 7, 81-101.

Cronan, J. E. \& Gelmann, E. P. (1975). Physical properties of membrane lipids: biological relevance and regulation. Bacteriological Reviews 39, 232-256.

Daniels, C. J., Bole, D. G., Quay, S. C. \& Oxender, D. L. (1981). Role for membrane potential in the secretion of protein into the periplasm of Escherichia coli. Proceedings of the National Academy of Sciences of the United States of America 78, 5396--5400.

ENEquist, H. G., Hirst, T. R., Harayama, S., Hardy, S. J. S. \& RANDALL, L. L. (1981). Energy is required for maturation of exported proteins in Escherichia coli. European Journal of Biochemistry 116, 227-233.

Evkokimova, O. A., Nesmeyanova, M. A. \& Kulaev, I. S. (1978). Indikutsiia sinteza shehelochnoi fosfatazy u $E$. coli preinkubatsieri kletok pri ponizhenno temperatyre. Biokhimiya 43, 1680-1687.

Fishman, Y., RotTem, S. \& CitRI, N. (1980). Preferential suppression of normal exoenzyme formation by membrane-modifying agents. Journal of Bacteriology 141, 1435-1438.

Gibbons, R. J. \& Banghart, S. B. (1967). Synthesis of extracellular dextran by cariogenic bacteria and its presence in human dental plaque. Archives of Oral Biology 12, 11-24.

Gibbons, R. J. \& Fitzgerald, R. J. (1969). Dextran induced agglutination of Streptococcus mutans and its potential role in the formation of microbial dental plaques. Journal of Bacteriology 98, 341-346.

GibBons, R. J. \& VAN Houte, J. (1975). Bacterial adherence in oral microbial ecology. Annual Review of Microbiology 29, 19-44.

hamilton, I. R., Phipps, P. J. \& Ellwood, D. C. (1979). Effect of growth rate and glucose concentration on the biochemical properties of Streptococcus mutans Ingbritt in continuous culture. Infection and Immunity 26, 861-869.

Hardy, L., Jacques, N. A., Forester, H., Campbell, L. K., KNoX, K. W. \& WickeN, A. J. (1981). Effect of fructose and other carbohydrates on the surface properties, lipoteichoic acid production and extracellular proteins of Streptococcus mutans Ingbritt grown in continuous culture. Infection and Immunity 31, 78-87.

Hoffmann, K. \& Tausig, F. (1955). The chemical nature of the fatty acids of a Group $\mathrm{C}$ streptococcus species. Journal of Biological Chemistry 213, 415-423.

JACQUES, N. A. (1982). Relationship between cyclopropane synthetase and the formation of cyclopropane fatty acids by Proteus vulgaris grown under various respiratory conditions. Journal of General Microbiology 128, 177-184.

JACQUES, N. A. (1983). Membrane perturbation by cerulenin modulates glucosyltransferase secretion and acetate uptake by Streptococcus salivarius. Journal of General Microbiology 129, 3293-3302.

JANDA, W. M. \& KuRAmitsu, H. (1976). Regulation of extracellular glucosyltransferase production and the relationship between extracellular and cell-associated activities in Streptococcus mutans. Infection and Immunity 14, 191-202.

Keevil, C. W., West, A. A., Bourne, N. \& Marsh, P. D. (1984). Inhibition of the synthesis of extracellular glucosyl- and fructosyltransferase in Streptococcus sanguis by sodium ions. Journal of General Microbiology 130, 77-82.

KimURA, K. \& IZUI, K. (1976). Importance of membrane fluidity in the induction of alkaline phosphatase, a periplasmic enzyme, in Escherichia coli. Biochemical and Biophysical Research Communications 70, 900-906.

Kito, M., Ishimaga, M., Nishihara, M., Kato, M., Sawada, S. \& Hata, T. (1975). Metabolism of the phosphatidylglycerol molecular species in Escherichia coli. European Journal of Biochemistry 54, 55-63.

MarR, A. G. \& Ingraham, J. L. (1962). Effect of temperature on the composition of fatty acids in Escherichia coli. Journal of Bacteriology 84, 12601267.

de Mendoza, D. \& Cronan, J. E. (1983). Thermal regulation of membrane lipid fluidity in bacteria. Trends in Biochemical Sciences 8, 49-52.

Nesmeyanova, M. A. (1982). On the possible participation of acid phospholipids in the translocation of secreted proteins through the bacterial cytoplasmic membrane. FEBS Letters 142, 189-193.

Pages, J. M. \& Lazdunski, C. (1982). Membrane potential depolarizing agents inhibit maturation of exported proteins in Escherichia coli. FEBS Letters 149, 51-54.

Petit-Glatron, M.-F. \& Chambert, R. (1981). Levansucrase of Bacillus subtilis: conclusive evidence that its production and export are unrelated to fatty acid synthesis but modulated by membranemodifying agents. European Journal of Biochemistry 119, 603-611.

Robrish, S. A., REID, W. \& KRICHEVSKY, M. I. (1972). Distribution of enzymes forming polysaccharides from sucrose and the composition of extracellular polysaccharide synthesized by Streptocoscus mutans. Applied Microbiology 24, 184-190.

Schachtele, C. F., Harlander, S. K. \& Germaine, G. R. (1976). Streptococcus mutans dextransucrase: availability of disaggregated enzyme after growth in a chemically defined medium. Infection and Immunity 13, 1522-1524.

UMESAKI, Y., KaWAI, Y. \& MUTAI, M. (1977). Effect of Tween 80 on glucosyltransferase production in Streptococcus mutans. Applied and Environmental Microbiology 34, 115-119.

Wittenberger, C. L., Beaman, A. J. \& Lee, L. N. (1978). Tween 80 effect on glucosyltransferase synthesis by Steptococcus salivarius. Journal of Bacteriology 133, 231-239. 